\title{
Cultural heritage and fortifications built for defence of the Strait of Messina in the late $19^{\text {th }}$ century
}

\author{
Massimo Lo Curzio ${ }^{1}$ \\ Università Mediterranea, Reggio Calabria, Italy
}

The two coasts of the Strait of Messina saw the construction of a permanent fortification in the late $19^{\text {th }}$ century/in the 1880 s, consisting of over 20 forts or coast batteries, for the defence of an area of the Mediterranean, which had always been of strategic importance for navigation ${ }^{2}$.

Since time immemorial, the centrality of the role of the Straits in the Mediterranean has, been object of great attention stimulating the collective imagination, as far back as Homer, and highlighting its singularity. Yet the myth of Ulysses and events associated with crossing the Straits are nothing more than a tribute to the uniqueness of the place, endowed with impressive natural beauty which stimulates fantasy and pathos.

Both scholars and travellers have alike been enchanted and have often abandoned themselves to reflection, as happened to Goethe, who, in 1787, on sailing out of Messina, is said to have been overwhelmed by the beauty of the sight of the coasts of the Straits, and by Scylla (Scilla) and Charybdis (Cariddi), a cliff and a rock, which have been identified in myths with dangerous, gigantic monsters.

The stories and suggestive tales described more recently by travellers and journalists have, instead, focused again on the fascination of the place, which should be seen beyond the mere material elements of the physical-geographical singularity that gave birth to this particular environmental feature, as Fernand Braudel recalls:

"On a world map, the Mediterranean is none other than a fissure on the Earth's crust, a molten Strait which stretches from Gibraltar to the isthmus of Suez and the Red Sea. Rifts, faults, subsidence, tertiary folding have all created deep liquid trenches and, almost as counterparts for those abysses, unending garlands of young, steep, rugged mountains. Near Cape Matapan there is a 4,600 meter trench, more than enough to submerge the highest summit in Greece, all 2,985 meters of Mt. Olympus. These mountains push toward the sea, often squeezing it so as to reduce it to a mere passage of salt water: Gibraltar, the Strait of Bonifacio, the Strait of Messina with the vortical whirlpools of Scylla and Charybdis, the Dardanelles and the Bosporus. It is no longer a sea: it is a series of rivers, or just sea portals" .

Two limbs of land facing one another, the result of what we can simply define as a geological discontinuity, beyond the seemingly peculiar image which meets the eye, actually make up a relatively easily accessible control passage, a particularly strategic location with regard to traffic and defence of the local people.

To understand the particular configuration and position of the fortifications of the Straits that were built at the end of the 1800s we must look at the historic models of this type of building and the actual construction model drawn up during planning and construction. 


\section{Fortifications and strongholds}

The aim of high-standing, raised fortifications has almost always been, to build an obvious stronghold, capable of signalling both an armed presence, and able to withstand an attack for possession of an area or human settlement. A fort had to be well visible, powerful looking, and capable of installing fear and awe, and territories were marked with particular points of resistance, which were generally entrenched in locations considered as strongholds.

More often than not, there was continuity between these strongholds, generally a rocky reef with an excellent view for control of the territory, and the structure built. Also physically, continuity seemed absolute; the construction was built over a base of stone (geological outcrop), and in most cases, of the same stone itself. This way of connecting a defensive bulwark built by man to a natural one was quite apparent and the high visibility of the emerging structure was accentuated by the shape of the building, with regular volumes, such as in the Norman or Frederick castles, or more complex buildings, according to the desire to adapt the fortification to the shape of the naturally occurring rock formation.

With the evolution of military techniques, in particular in the historic phase which marks the passage from the medieval to the modern age, highly technical constructions were developed.

\section{Renaissance expression of fortifications}

Leonardo da Vinci's designs, like those of Antonio and Giuliana da Sangallo, and many successive works, show how the plan and development of proposals to improve weapons tended toward perfecting characteristics of defence, by optimizing the possibilities of replying to attackers deploying troops in the best possible way.

Solutions were created which gave a precise geometric configuration to the bastions, watchtowers, ravelins and caponiers, based on the use of cross-fire. These studies were the starting point for modern fortifications. Although born as solutions drawn up by single military architects in an un-codified way, they soon became routine and were used to face new methods of warfare which developed as firepower increased.

New ways of confronting clashes between warring sides, with improvement in techniques, made it possible to manage battles and conflicts and led to the theory of a true 'military revolution', that is, a different way of conducting war, as identified by historian Geoffrey Parker ${ }^{4}$. The actual expression 'military revolution' was first used by historian Michael Roberts ${ }^{5}$ referring to crucial changes in the art of warfare ${ }^{6}$. In effect, the historic phase from the end of the $15^{\text {th }}$ century to the $18^{\text {th }}$ century saw so many conflicts, that there were more periods of war than moments of peace.

As is known, the passage from a defence based on launching or dropping objects from on high to a closer, more precise grazing defence completely changed the method of conducting warfare and, as a consequence, transformed fortification construction. Previously, construction was tied to the power of attack of very imprecise cannon balls, which were launched with a parabolic trajectory; now, the possibility of attack with howitzers and more precise cannons with a grazing shot, which, from the $19^{\text {th }}$ century devastated the rifled artillery, was taken into consideration during construction. 


\section{Town defence and entrenched camps}

Along with the logic of using precise, sporadic defensive mechanisms to defend important military locations, valley passes or in particular environmental situations, over time, the strategic role of vast areas surrounding the main European cities, or critical points for communications control and vital economic areas for survival and development, came under consideration.

With the rampant flourishing of the great European cities, which became important economic and communication centres, territorial defence became a strategic question of dealing with wide spaces which were no longer defendable with a single fortified structure or old city walls. This new perception of cities modified thinking on the defensive capacity offered by permanent fortifications such as castles and towers that were, even if linked to a plan of defence, isolated and distant, and led to a completely different way of providing territorial defence in highly strategic areas.

The yardstick for creating this new defence plan stemmed from the modified way of conducting warfare, which, in itself, derived from the change in weapons and type of attack. The military revolution, brought about by the invention of ever more precise, stronger weapons, imposed a variation in the typology of fortifications which now had to resist new assault tactics, in particular, the ability to withstand the impact of new large guns which, with explosive shells, could easily perforate the walls.

Ramparts and defence structures, which had been radically redesigned with Renaissance models and later subjected to further strengthening, now became obsolete and inadequate as howitzer fire and cannons became stronger and defence tactics changed, as mentioned previously. Rifled gun-carriages, an increase in the gun-range of shells, a tighter, more penetrating shot, the strengthening of explosives in shells were all elements which redefined the international war arena with continual, unstoppable modifications in the race for more effective, devastating weapons ${ }^{7}$.

The positioning of defensive structures was strictly correlated to the range of the howitzers and cannons, shifting the lines of defence. Before 1850, the line of defence could be placed at 2,500 metres, but already between 1859 and 1863 , a Belgian general, Brialmont, set a distance of 3-4,000 metres between the distanced forts and the revetments when defending Anversa Square ${ }^{8}$. Between 1860 and 1870, the Austrians increased these distances in Linz and Verona. From 1870, the use of rifled artillery meant the doubling of the range of large guns and, during the Franco-Prussian war, the Prussian army destroyed the imposing French fortifications without any difficulty ${ }^{9}$.

\section{Entrenched camps and defensive structures in Europe}

The defence of European capitals and strategic areas was totally revised with the creation of entrenched camps, in particular in the period following the Napoleonic wars. It was well received by municipalities and the people themselves, being based on the idea that the extra urban defence walls could keep the enemy at bay and better guard the safety of the town and activities carried on within. Defence, and any possible attack, would be carried out beyond the urban perimeter and an 
ample protective wall. War would not touch the citizens and the defence was to be on the shoulders of the armed forces. A very reassuring picture had been so drawn.

This consensus, which rapidly spread across the nations, led to the building of huge, protective city walls and created a model of 'detached' fortifications which could be constructed in different versions, suitable for any firing system required.

The most important entrenched camps, in the first phase, were those in Coblenza, started in 1816, Paris, 1844 and Verona in $1835^{10}$. Among these, the entrenched camp in Paris is worth noting as, in just a few years, the city walls were closed, and 16 detached buildings were erected.

The entrenched camp of Verona was built by the Austrians to avoid a repeat of the damage sustained during the Napoleonic campaign of 1796-97, and to ward off any possible invasion of Veneto from the west. Building took place in many phases from 1835 to 1866 and was based on a double line of various types of forts built on flatland. The distance between the closest line of the forts and the city walls varied between 400 and 1,800 meters $^{11}$.

\section{National defence of a unified Italy}

In the second half of the $19^{\text {th }}$ century, the problem arose of defending the territories and borders of a newly united Italy, in 1869. The novelty of the situation led to wide debate, which lasted several decades. Proposals to be adopted and the logic of defensive structures to be built, put forward by politicians and the Army and Navy Forces, favoured entrenched camps and permanent fortifications, recalling traditional defensive mechanisms of national borders throughout Europe and other parts of the world, with the ultimate aim of protecting areas of high strategic value ${ }^{12}$.

Entrenched camps built in several European towns were previously conceived as fortified walls built, in most cases, to defend towns and cities which were vital for the development of the nation. The policy of the newly unified Italy, apart from defending the most important cities such as Rome, focused on areas of national territory which were characterised by particular geographic features. The fortifications of walls in the Alpine zone and in the area of the Strait of Messina were included in this. The historic role of these works, above all the defence of the Straits, was strictly connected to the national programme of interventions at a time when an attack by a foreign power was deemed highly probable, especially from those nations with expansionistic goals, for example, France.

The national debate which involved both the Department of Defence and Parliament led to necessary strategic choices. The Strait of Messina, it was agreed by all, was of fundamental importance for national defence, and both politicians and military personnel indicated that the answer was the construction of a defence structure. The only difference between politicians and military was the actual number of works to be carried out, considering the financial resources available ${ }^{13}$.

The military role of the city of Messina was highlighted as the most important nerve centre. In the past, its development was unquestionably tied to defence purposes and military installations which were purposely built or adapted. Fortifications and bulwarks had many times changed the face of this city, contracting or expanding it, changing the limits between city and countryside, signalling or highlighting, in different ways, the importance of its strongholds ${ }^{14}$. 


\section{Permanent fortifications of the Straits built in the late $1^{\text {th }}$ century}

In 1884 , a programme was initiated to build permanent structures deemed necessary for the defence of the Strait of Messina, which had been identified by the mixed Commission for Defence as being of fundamental importance for State security. Moreover, given that the Mediterranean Sea was frequently crossed by the fleets of the most important European nations, with their expansionistic hopes, a possible attack from sea was feared. It was for this that the permanent fortified structures to defend the Straits were proposed and, from the beginning, a coast battery, capable of countering possible enemy troop landings, was envisaged.

In comparison to contemporary Italian entrenched camps placed in other highrisk areas, such as on national borders or the most important cities, the permanent fortification planned for the defence of the Strait was quite particular, incomparable to other situations, as it was created to protect a sound which interrupted the physical continuity of a nation. This is something worth noting, as it highlights the climate of defence of the then newly unified State, as can be inferred from the directives issued for the defence of national borders, and the theoretic and technical expertise of the Engineers Corps, who were responsible for planning the entire defence system.

In addition, the question of the defence of the Straits can also be examined through the writings of Borgatti: "The re-enforcing of the Straits will be carried out at high speed, and the blockage may be either continual, with obstructions which will require exceptionally favourable sea bed conditions, or with fortifications, in which case the Straits must not exceed a desired width for firing against fast moving targets, from cannons on both sides of the shore. This width should not be more than 4 or $5 \mathrm{kms}$. Straits which join two seas can be fortified, as in our case with the Strait of Messina, so as to guarantee passage of one's own fleet and hinder passage of the enemy's. The width can then be longer than indicated above as it would not be in the interest of an enemy fleet to cross the straits with its inherent risk, when they can reach their objective by taking an alternative route. The Straits can therefore be considered a port of shelter, open at two ends, and the enemy fleet, should they judge so, will attack it like a common maritime town"15.

\section{Features of the fortifications in the area of the Strait of Messina}

Fortifications built in the last two decades of the $19^{\text {th }}$ century on both sides of the Straits cannot easily be compared to the same type built in other parts of the country, or elsewhere, as the geo-morphological and environmental features are so dissimilar to other areas of interest for defence, making them unique.

The policy of the Army, which was then implemented with plans drawn up by the Engineers Corps, used a model of fortifications which derived directly from the state-of-the-art of European fortifications of the time. According to this model, fortifications were to consist of a more bruising, efficacious type of defence, to be conducted with fixed artillery ready to cover a wider range, with mortars and latest generation rifled cannons, to intercept possible attackers. Thus, a simple fort model was used which was essentially destined to house a firing battery to intercept the enemy at a distance. 
The essential difference between building the defence walls in the Alps, Veneto and Rome, and in the Strait of Messina was the fact that the place of attack in the latter was the sea, and the means were the latest generation of warships. The defence system had thus to be updated and, given the diverse attack logistics, the deployment of the defence structures was changed and placed on high ground, so as to be able to more easily target ships at sea.

As the shores of the Straits are quite rugged, due to the presence on the Sicilian side of the Peloritan mountains, and the mountains of Aspromonte on the Calabrian side, it was decided to make the fortifications invisible from sea, the principle area of engagement, and to protect the remaining areas in more traditional ways, with trenches, caponiers and drawbridges, should the battery be outflanked on land.

\section{Connection between the fortifications of the Strait of Messina and the surrounding territory}

The particular positioning of the $19^{\text {th }}$ century fortifications, originally determined by a strictly military choice of observation and firing posts, appears to have been well made. Military installations in the Straits were positioned in extremely well favoured, panoramic points. Territorial congruity provides yet another enhancement factor for this national heritage.

If the general hypothesis is that the military installation was not invasive, nor visible from the Straits, it is evident that the construction characteristics responded to an architectonic model which is totally compatible with this need: the fort was not be visible to possible attackers, but was to be highly efficacious and easily maintained.

From this we are talking, for obvious planning needs, of an essentially underground architecture, to be inserted in hill or plateau areas, following certain modification of the facilities. There are structures made from earth, stone and bricks which blend in with the robustness of its position, rooted, as such, in the earth, with the need for passageways and viable connections, even under enemy fire, allowing movement of fire arms and an efficient system for easily handling equipment. This is an apparently 'natural' architecture, simple in its essence, which dialogues directly and without trauma with the territory, and which adapts to its surroundings, establishing new rules of maximum environmental compatibility, leading to the highest level of shape adaptation, the lowest level of external development and therefore, the highest efficiency.

\section{Military presence and visibility}

The reasoning behind the military batteries guarding the Straits was significant as it overturned the idea of deterrence based on visibility of strength. In the distant past, transformations to the land and landscape were striking, while now structures were invisible and underground, but capable of surrounding enemy craft with crossfire to ensure complete coverage of the entire stretch of waters of the Straits. The difficulty of the enemy in identifying the exact position of the batteries was due to the fact that there were no emergences or structures visible from the sea, and because of their position, on the hills, distant from the coast. This effective defence solution depended completely on the range of rifled cannons and the spread of firing cover from each post. As more than twenty battery posts protected 
the two sides of the Straits, the possibility of intercepting the enemy was guaranteed by overlapping fire and complete coverage.

This series of fortifications is about twenty kilometres in length, in a northsouth direction, with a transversal coverage of the Strait of Messina, which goes from a minimum distance between the two shores of 3,300 meters, on the northern end, to 10,000 meters at the mouth of the southern end. Gun coverage ensured protection of over 133 square kilometres of water, and there arose the ambitious programme, within defence objectives of the time, of conditioning the workings of the entire traffic of the central Mediterranean.

In reality, the elaboration of the unique model used for building in the Straits, particular in its high plain positioning, could not be compared to an entrenched camp. The latter foresaw the defence of a perimetric space toward the outside. In the case of the fortifications of the Straits, this logic was reversed: defence was placed on the two sides and directed internally, hindering an attack from the enemy at sea. The closed area of the entrenched camp to be protected was missing, and instead, natural features were given great importance. The installations on the Calabrian side had the slopes of Aspromonte behind them, while on the Sicilian side, there was the natural bulwark of the Peloritan mountains.

Posts not overlooking the Straits, on the Sicilian side, looked onto valleys which allow control of the passage from the Plain of Milazzo and therefore determined the positioning of four batteries in this direction, to defend from a possible landing from the Tyrrhenian Sea. In some drawings from the Engineers Corps from 1884, we find the words 'entrenched camp', along with relevant tracings of firing trajectories. This, we think, referred to the area controlled by these batteries, which were ideally placed for that eventual landing, because of the particular position of the wording on the plans.

A further consideration on the particularity of this system of $19^{\text {th }}$ century fortifications can be made given that response to attackers was conceived as rapid and immediate, contrary to the logic of entrenched camps, which were born essentially in response to siege warfare. Enemy vessels were not to have any possibility to rest and stop to disembark troops. It was for this that the passage through the Peloritan mountains from the plain of Milazzo was defended, given that the lesser slope of the land could facilitate disembarking and outflanking of posts on the Sicilian side of the Straits.

\section{Variations in the organization of the batteries}

The shape, distribution of spaces and size of the different batteries is worthy of attention.

We have identified four different construction solutions based on the general model of organization of these defence structures, which we categorize as four variations of a single model. The internal organization was originally a single plan, and the distinctions proposed are purely functional and descriptive, in an effort to interpret the finalization and use of the variations.

\section{Large sized Batteries}

The first two batteries were Matiniti Superiore, later renamed Siacci, in Campo Calabro on the Calabrian side of the Straits, and the Polveriera battery, later renamed 
Masotto, in the commune of Messina on the Sicilian side. They have essentially the same shape and are important for size and high number of usable spaces, which meant they could house large numbers of troops. Their shape, originally trapezoidal, was modified by the juxtaposition of a triangular ditch on the mountain side, with a scarp and counterscarp in solid stone masonry. They differ from others in their high ground position. Here, a lower unevenness of the ground meant there were more architectural possibilities. However, the model was later abandoned, due to high cost and difficulty in building and maintenance.

\section{Medium sized Batteries}

Most constructions fall into this category. They are based on a regular, quadrangular shape with three sides closed by earth ramparts, and on the side of the mountain by a ditch, caponier protection and drawbridge at the entrance. These elements are laid out in a precise symmetry, emphasized by the centrality of the parade ground and the double access ramps at the level of the large guns. Compared to the organization of larger sized batteries there was less space, and far less troops could be housed.

\section{Small sized Batteries (more or less protected by larger sized batteries)}

These batteries guarded the Straits from nearer the sea and were often aligned with higher up, larger sized batteries. They were minimally developed in organization and height, and were built with less digging, excavation and infilling. The choice of this type stems from the proximity of the main firing front to the coast.

\section{4. 'Mountain' Batteries}

There were many batteries in this category, and were generally positioned on the highest ground of the Peloritan mountains, deliberately using a simple construction. They are all to be found on the Sicilian side of the Straits and were destined for the protection of internal communication lines.

\section{A historic, architectonic and environmental heritage}

The fundamental question which arises from relevant historic data concerns what to do with regard to this particular type of public architectonic heritage, which has a singular, environmental value, due to the choice of structures and extraordinary panoramic location.

This architectonic heritage was born as, and remains, by Italian law, public property and should be suitably protected and conserved, both, as is due to forced heritage of the State ${ }^{16}$, and for the significance that these batteries have as evidence of a particular historic moment, receiving therefore, all respect this material documentation of the tradition of fortified works deserves. Its singular value and significance lies in having marked a land endowed with particular geographical features, and favouring a specific relationship between these fortified structures and the environment of the Straits.

The need for environmental protection for architectonic heritage should not seem singular nor anomalous, nor forced in the cultural elements it contains. It is well known that defence structures (be they for the territory or city) are examples of advanced anthropization and show the desire for continuity of a determined territorial order. 
Historically, the issue revolves around the role of an enemy which loomed on the horizon at the close of the $19^{\text {th }}$ century, an imminent threat which directly led to the permanent fortification of the Straits. Although fortunately little used for military purposes, today they form part of a single national, architectural environmental heritage, structures that can be restored and used despite their raison d'etre.

\section{Conservation of the permanent fortification of the Straits of Messina}

This heritage is considered, first of all, as unitary, an expression of the historic event of setting up of a defence system, within a national policy, to safeguard the area from possible attacks by an enemy power. To correctly understand what measures should be taken, the characteristics of this type of heritage should be carefully examined so as to protect it adequately and made it useable; however, useable only according to absolute compatibility.

It would be a grave error to consider this heritage as being simply made up of a certain number of different, separate entities, so much so as to create problems in planning preservation works that finish up by merely delimiting the area. It is quite the opposite. This heritage structure concerns the entire series of coast batteries and fortifications built in the same period. It is to be considered as a single piece, a single historic document, precious in its expression of the design of the Italian Engineering Corps, in a precise historic period. It must thus be preserved as a unique project.

A further consideration on the preservation of these structures is that they are the only architectonic heritage of this type in the area to have survived the catastrophic earthquake, completely intact, in the Straits of Messina, in 1908.

The earthquake of 1908, which saw the destruction of the cities in the Straits, Messina and Reggio Calabria in particular, with nearly 100,000 victims, is universally remembered as one of the most devastating natural events of the $20^{\text {th }}$ century. It was this seismic event which led to the birth of innovative technological solutions and anti-seismic constructions based on framed structures, adopting different techniques ${ }^{17}$ which fundamentally refined, above all wooden framed structures, some technical devices and construction systems already adopted 125 years previously, after the Calabrian earthquake of 1783 . From the reconstruction of the cities on the Straits, immediately after 1908 , the myth of reinforced concrete framed structures as the ideal solution for safe, long-lasting buildings, was created.

Yet, the guard batteries of the Straits were built twenty years before the 1908 earthquake, using neither innovative technology nor framed structures. Rather, they were based on raised structures in mixed masonry and on traditional vaulted structures, an acceptable solution and, as confirmed by history, extremely long-lasting. If anything, these structures show how the correct use of traditional structures and solutions based on works of relief and infilling can work, considering that today these structures are practically intact, with simply a few cracks due to subsidence or cave-ins, due, above all, to external causes ${ }^{18}$, along with light damage due to lack of maintenance.

\section{Architecture and environmental protection}

The fortifications have been identified as environmental heritage based on certain considerations. The first is that the identified system is historically significant 
in its localization and structure, in an area which is important both from a landscape and environmental point of view. The second, strictly connected to the first, is that not only has it not created any modifications to the environment, but, is an expression of congruity in maintaining the panorama of the Straits. The third is that the location was chosen for the defence battery in the Straits for its exceptional view points and panorama of the entire territory.

One need not be an aesthete or environmentalist to recognize the beauty of the panorama over the Straits from these $19^{\text {th }}$ defence structures, unique in what they offer in their natural setting. Environmental heritage needs to be revaluated and preserved and no longer neglected. This means drawing up a program of preservation which is precise and feasible, within determined time limits, similar to landscape protection which foresees "maintenance of features, of constitutive and morphological elements, also keeping in mind architectonic typologies, as well as techniques and construction materials" 19 .

Furthermore, this defence structure as heritage, created during the war, may have a sense today, should it become not only an example of a proper conservation but also an example of an open, territorial structure, used in a proper social and public way.

\section{Interventions on the heritage of the fortifications and codes of behaviour}

Heritage conservation needs to extend over a wide field, from the need of simple maintenance interventions to recomposing damaged parts or re-establishing a compromised environmental balance. Thus, a code of behaviour should be applied with the aim of both directly protecting the object or place being worked on, and achieving the correct quality level of the plan and intervention themselves ${ }^{20}$.

The aim of the code should be to avoid excessive, overworked plans which often add structures, destroying the integrity of the object or place in hand. Engineering based projects of consolidation often give negative results, as there is recourse to hi-tech or hybrid solutions which alter historic structures, even provoking various degrees of instability, due to incompatibility of materials. A code regarding ways of approaching historical architecture should include minimally invasive, feasible interventions starting from the notion that the bigger the proposed transformation of a structure, the higher the risk that the final outcome may be questionable, compared to the original information and character of the structure.

This is particularly dramatic when, as in our case, the object of intervention is; a) not thought of as being sufficiently important, or 'monumental'; b) not a single object, but rather an element of an architectural complex built in one period. In this case, the need to maintain the original character is fundamental, along with conditions of use which are compatible with the typology of the cultural heritage, respecting its inherent architectonic elements ${ }^{21}$.

The above mentioned codes of behaviour, seen as an actual enactment of intentions and general indications of various guidelines on restoration and conservation, might indicate limits and planning possibilities of appropriate interventions. The Declaration of Amsterdam, 1975, with the introduction of the principles of integrated conservation, raised the issue of use, with determined functions, of 
architectural heritage. Politically correct logic is that, only if a determined architectural structure is put to use, and if economic resources are guaranteed for managing and maintaining it, can an important structure be kept 'alive'.

An international code of behaviour could, one day, lead to coordinating interventions on architectural heritage, meeting wide ranging, international needs. The right setting needs to be fostered, to allow the establishment of an information network to link up end points and critical events for both single architectural elements, and larger, more complex entities, without neglecting structures which have determined different territorial usage.

In our case, this intention is applicable in terms of definition of rules which are acceptable to the scientific community, and applicable in different situations without giving rise to difficulty in interpretation, and with easily understandable methods. There is the need to create a database related to diverse architectural structures and markers which can be traced throughout a territory, and which have been indentified as highly significant in the history of the communities in the area.

The resulting database could become the first element in the systematic organization of information, with the help of the scientific community and the use of pubic and private institutions, via Internet ${ }^{22}$. Difficulty in using a common system of information gathering could be resolved with the use of suitable databases provided by scholars and researchers, via Internet, in universities and research institutes. Globalization of communications could significantly contribute to diffusing knowledge on architectural and environmental heritage.

Knowledge of available data should be the first step in structuring communications, thereby improving efficiency in preservation and safeguarding interventions, on a national basis, given the vast range of situations involved. Realistically, IT systems are the only way to coordinate the so many different realities, both from the point of view of interventions foreseen, and the enormous differences between the experts involved in such a project. With IT systems, information gathering, sorting, categorizing and re-elaboration becomes more feasible, and the resulting database can contribute in an extremely practical way to a truly common, shared reference system.

Reasoning from the conservation of a particular type of cultural heritage to the point of external relationships involving exchange of data on a world basis may seem demanding and/or excessive. In reality, however, this reasoning is linked by two obvious considerations. The first is that without communications, information and culture cannot spread. In our case, information and culture are not concerned only with historic data, but involve both tangible and experimental data, dealing with real life problems and experience. The second is that the spread of culture on-line is so relatively easy and immediate as to encourage exchanges in a totally democratic way.

Simple rules are required.

Even if coordinated principles and rules put together by the international community can extend ways of protecting historic heritage, there still remains the problem of 'codes of behaviour', which should concern ways of studying and intervening on single projects, outlining simple, easy to understand actions/proposals, giving the same possibilities to poorer regions or nations as richer nations can avail of $^{23}$. 
The only way to unite poorer and richer realities in the protection of architectural and environmental heritage is in using controlled interventions, starting on a small scale, with the manual and artisan approach that was used by those who created the structure that has now to be conserved. This would mean, for instance, that the first standard intervention to be verified in a structure would be the method of constructing the walls. Masonry, whether realized in stone, brick or mixed techniques, should help determine the original use of the structure, after examining the manual labour and rules used by the builders.

Well bonded, well presented masonry will show the quality of the vertical structure of the building. Without knowing the true consistency of the masonry it will not be realistically possible to evaluate the restoration and maintenance needed. The same principle should be adopted for the study of other structural elements of the building. Horizontal structures (roofs, ceilings, vaults) should be considered according to their function, and would be fundamental in identifying the characteristics of the building. By studying and analysing how the brickwork and annexed structures were built the reasoning behind the choices made by planners can be identified. Thus, the architectural tradition expressed by the building can be unquestionably traced. Altering the characteristics of a building or architectural complex with incompatible modifications and transformations means completely changing the body of the structure, debasing or annihilating the historic significance of this structural document.

The objective is to tend toward recuperating and conserving architectural documents compatibly with the diverse needs arising in as many different situations as possible. The reacquisition of manual capacity in carrying out interventions is also envisaged as it would give direct, immediate control over the work. Thus, work being carried out avoids an undifferentiated, uncritical contribution deriving from the use of improper technology or procedures which lead to solutions that are difficult to control, and divorced from building tradition.

\section{Endnotes}

1. Associate Professor of Architectural Restoration, Università Mediterranea, Reggio Calabria, Italy. Coordinator at UM, Reggio Calabria for the International Master program EMDiReB - European Master in Diagnosis and Repair of Buildings, and Head of Specialization course in Conservation and Restoration of Historic Architectural Heritage.

2. Cfr.: M. Lo Curzio - V. Caruso, La fortificazione permanente dello Stretto di Messina, Storia, conservazione e restauro di un patrimonio architettonico e ambientale, EDAS., Messina 2006.

3. F. Braudel, Il Mediterraneo. Lo spazio la storia gli uomini le tradizioni, Milano 1997, pag. 11.

4. G. Parker, La rivoluzione militare. Le innovazioni militari e il sorgere dell'Occidente, Bologna 1989.

5. M. Roberts, The Military Revolution, Belfast 1956.

6. Michael Roberts identified historic changes in warfare, as follows: 1 . Revolution in tactics with the substitution of spear and pike with bow and musket; 2 . Increase in the size of armies in Europe, which, between 1500 and 1700, grew ten-fold; 3. More ambitious, complex strategies; 4 . The impact of war on society regarding resources used, damage and administration difficulties. 
7. For a complete, systematic view of issues related to the history of modern fortifications, different models used in Europe, requisites for fortifications and choice of location, planning and building, see M. Borgatti, La fortificazione permanente contemporanea (teorica e applicata), Torino 1898.

8. This theorist on fortifications is attributed with having a particular role in experimentation and setting up of entrenched camps. Cfr., in particular: A. H. Brialmont, Traité de fortification polygonale, Bruxelles 1869; A. H. Brialmont, Les régions fortifièes. Leur application a la défense de plusieurs états européens, Bruxelles 1890.

9. Cfr.: P. Brunello, La deterrenza impossibile: i campi trincerati in Europa (1860-1915), in C. Zanlorenzi (a cura di), I forti di Mestre, storia di un campo trincerato, Verona 1997, pag. 17.

10. M. Borgatti, La fortificazione permanente contemporanea, cit., pagg. 101-106.

11. Ibidem.

12. The study of defence systems in the new State began in 1862 with the setting up of a mixed Commission, directed to report on the use of existing, and future, military structures. The work of this Commission is the basis for the main constructions of the 19th century.

13. It should be noted that the Permanent Commission for Defence, from its onset in 1862, proposed general issues to be dealt with in deciding on efficacious interventions for the defence of the Nation. In the phase which ends on 17.02.1886, the order of precedence of works in the Strait of Messina was decided (Dispaccio n.2018). Up to that date, only works for the batteries in Matiniti superiore (Calabrian coast) and Polveriera (Sicilian coast) had been started.

14. Cfr. for a complete analysis of fortifications in Messina, see: F. Chillemi, Mura, torri e fortificazioni, in R. Sisci - F. Chillemi - M. Lo Curzio, Messina. Fortificazioni e Arsenali, cit.; for the relationships between fortifications and modifications in urban planning in Messina, see; M. Lo Curzio, Per una lettura della configurazione urbana e delle modalità d'intervento, with designs by Antonio Amato, ibidem.

15. M. Borgatti, La fortificazione permanente contemporanea, cit., Parte II, pag. 103.

16. Fortunately all these installations are state property. This fact, along with the policy of contracting out to experienced individuals in the last decade, has meant the survival of a heritage which is at risk, due essentially to lack of maintenance, and plundering by illegal users.

17. For the reconstruction of the cities of the Strait of Messina cfr.: G. L. Di Leo - M. Lo Curzio, Messina una città ricostruita, materiali per lo studio di una realtà urbana, Bari 1984; R. M. Cagliostro, Ricostruzione e linguaggi, Reggio Calabria: per una storiografia delle scritture architettoniche dopo il 1908, Reggio Calabria 1981; A. Marino O. Milella (a cura di), La catastrofe celebrata. Architettura e città a Reggio dopo il 1908, Reggio Calabria 1988; C. Barucci, La casa antisismica Prototipi e brevetti, materiali per una storia delle tecniche e del cantiere, Roma- Reggio C. 1990.

18. The worst damage was from war, illegal transformations or improper demolition.

19. Cfr.: Codes for Cultural Heritage and Landscape (Codice dei beni culturali e del paesaggio), art. 143, comma 2 a.

20. With regard to the formulation of proposals for codes of behaviour, cfr.: M. Lo Curzio, Historical Architecture, urban retrainings and maintenance of a patrimony at risk in Italy in Reconstruction and the politics of space (Atti $7^{\circ}$ Conferenza IASTE, Center for Environmental Design Research, The end of Tradition?), Volume 131, IASTE Working Paper Series, University of California, Berkeley 2000; published in Italy with additional notes as M. Lo Curzio, Conservazione di Architetture e Centri Storici, dal caso italiano possibili regole e codici in I Paesaggi della tradizione, ed. by A. Petruccioli and M. Stella, Bari 2001. 
21. The extensive use of reinforced concrete in consolidation interventions peaked in Italy during reconstruction of the cities of the Strait of Messina, destroyed by the 1908 earthquake. From the first laws issued in 1909, reinforced concrete, to be used in building framed structures, was given ample field of use. It was seen as a solution to all building ills, and from then on gained so much credit as to be used in repair to historic buildings which had survived the earthquake, or considered indispensible for reconstruction or completion of the most important buildings. The legitimization of a technology which joined 'artificial stone' to steel was so unequivocally successful that it was, in a sense, sanctioned by the Declaration of Athens and the Declaration of Italy on restoration, in 1931, when construction means, similar to ancient methods, were not sufficient for 'reinforcing' or 'reintegrating'; in these cases 'modern construction means' could be used. In reality, with this policy of consolidation with reinforced concrete, we have the basis for a policy which, beyond the unconcern of behaviour, piloted structural transformation of buildings, according to the thaumaturgic possibilities of this new material and new science, thus dramatically influening the question of materials and structural alterations. This then conditioned the authenticity of architectural heritage as a true historic document.

22. The prime need is therefore to start with structures which have already been declared World cultural heritage by international organizations such as UNESCO, and add to this, architectural and environmental heritage which has been listed by different nations for conservation for future generations.

23. This proposal stems from the awareness that a certain level of knowledge and exchange of databases on world architectural heritage is missing, at the same level as environmental and artistic heritage, and that this delay hinders the international community from accessing both the knowledge itself and the material available, if only to know what is to be protected for future generations. Internet, the only realistic solution for communicating amongst people, following criteria unconditioned by stronger economic forces over weaker poorer forces, could allow a level of exchange which would overcome initial information gathering difficulties. 


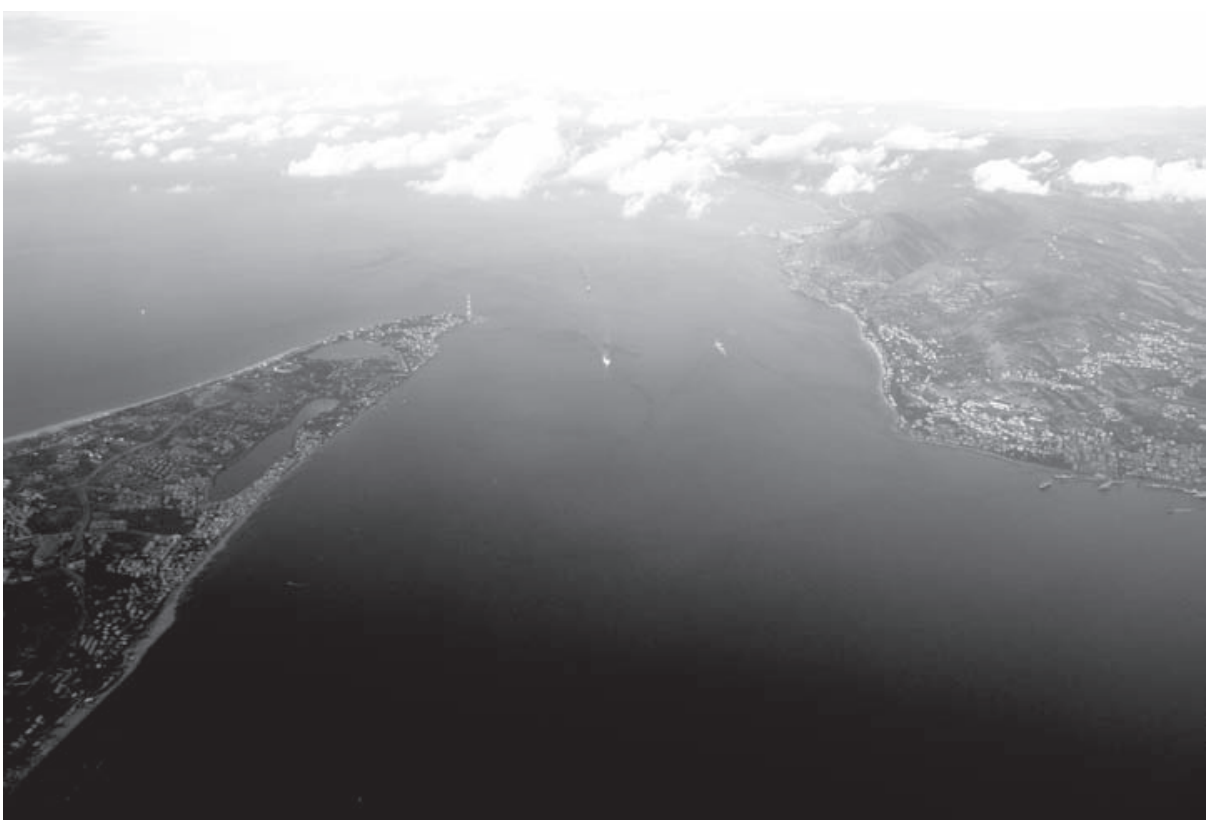

Fig. 1. The Strait of Messina, aerial photo to north.

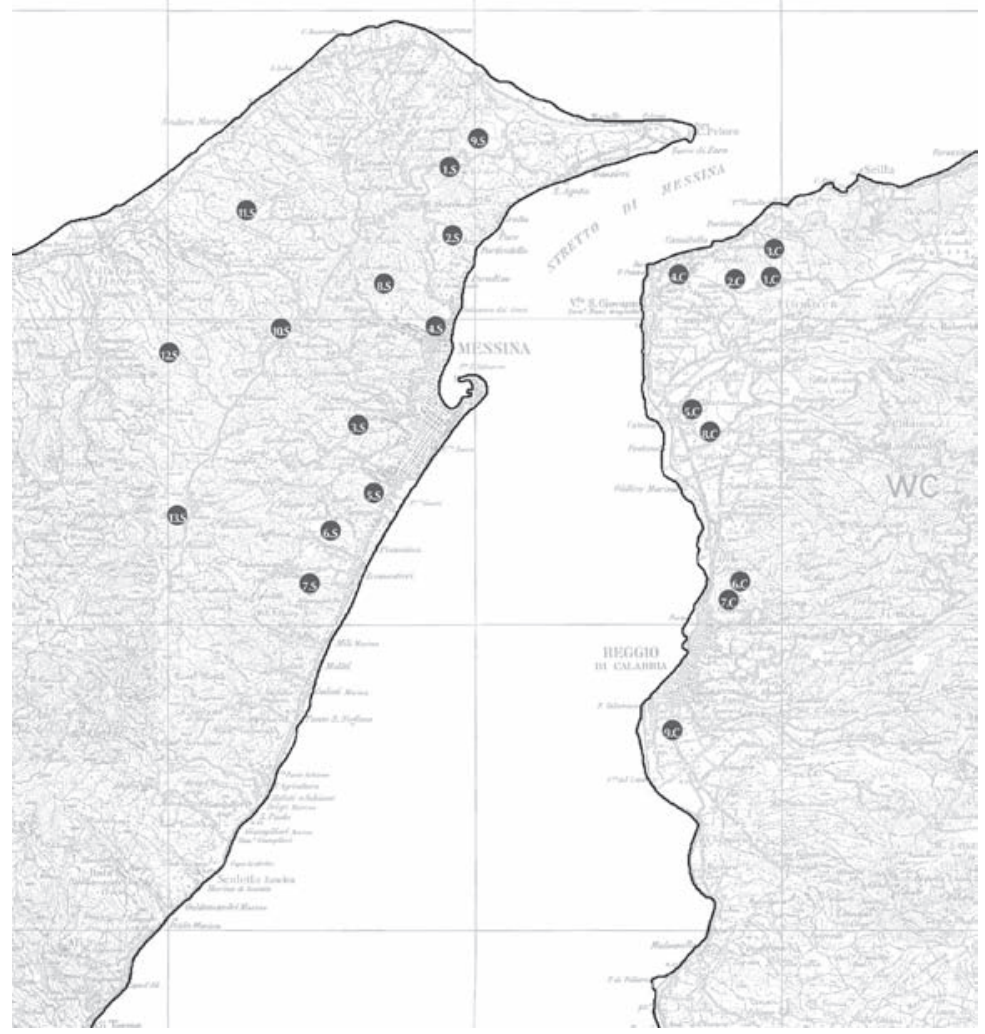

Fig. 2. Location of the Coast Batteries along the two coasts of the Strait of Messina. 


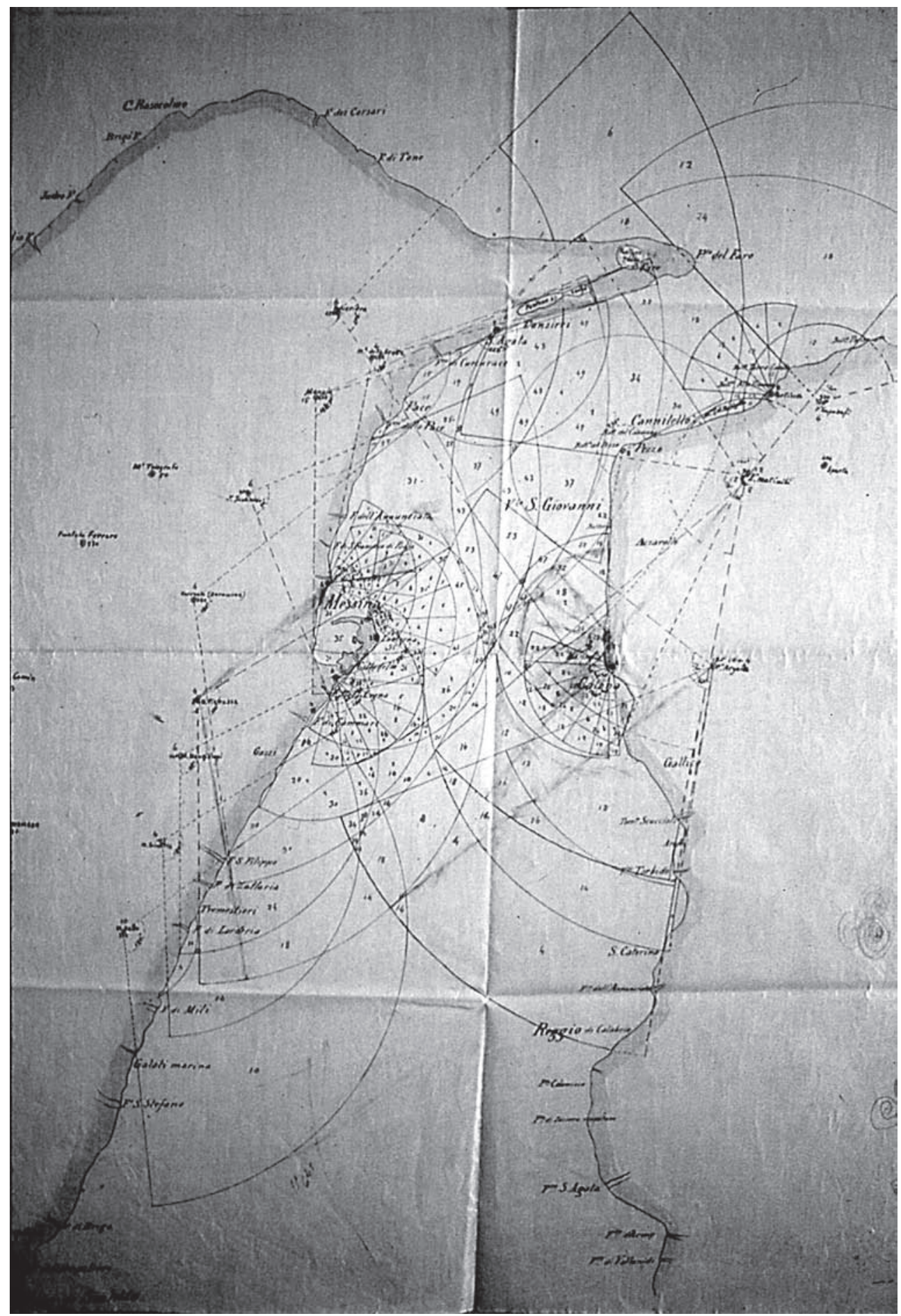

Fig. 3. Plans of the shots of the batteries. Archivio dell'Arma del Genio, Rome. 


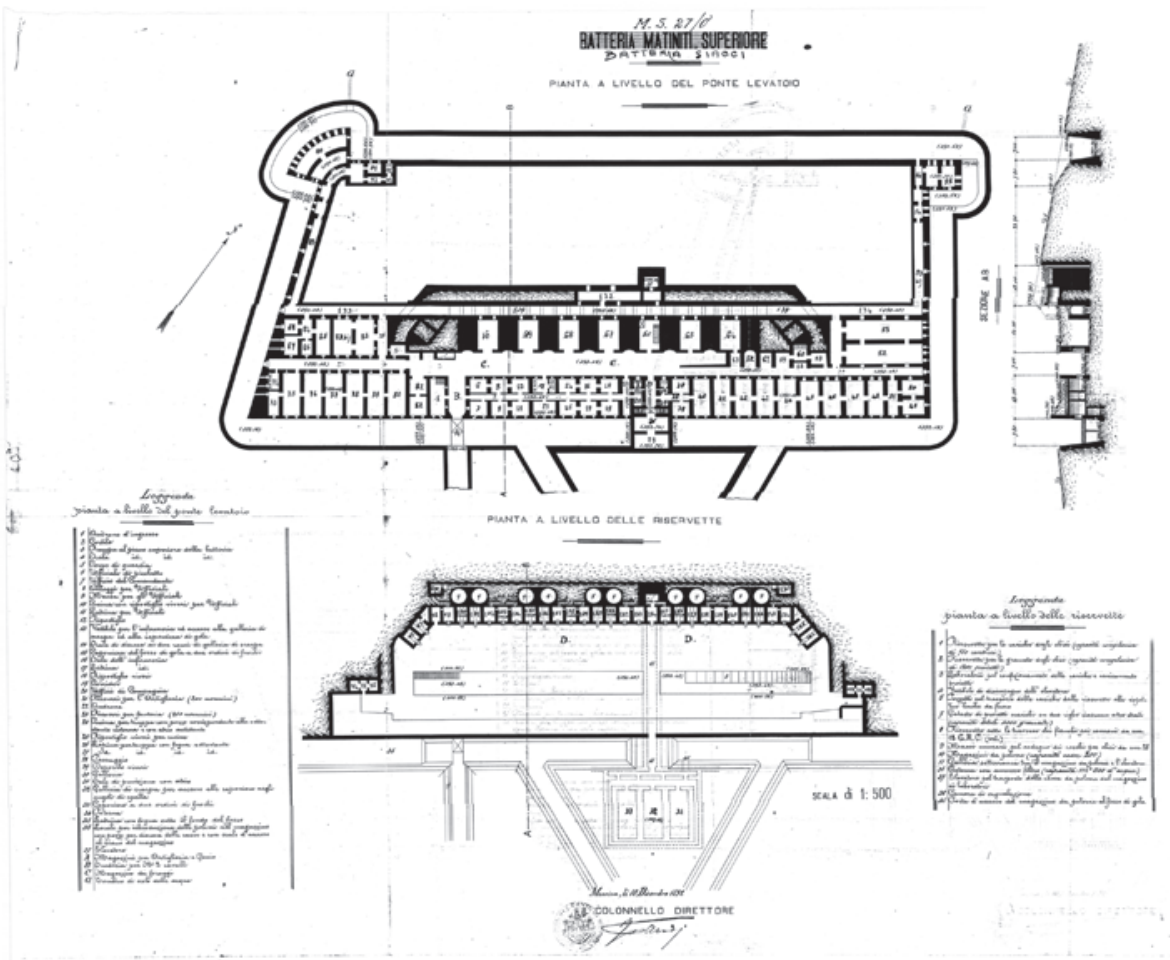

Fig. 4. Coast Battery Matiniti superiore or Siacci, 1C Calabrian coast, plans and cross section.

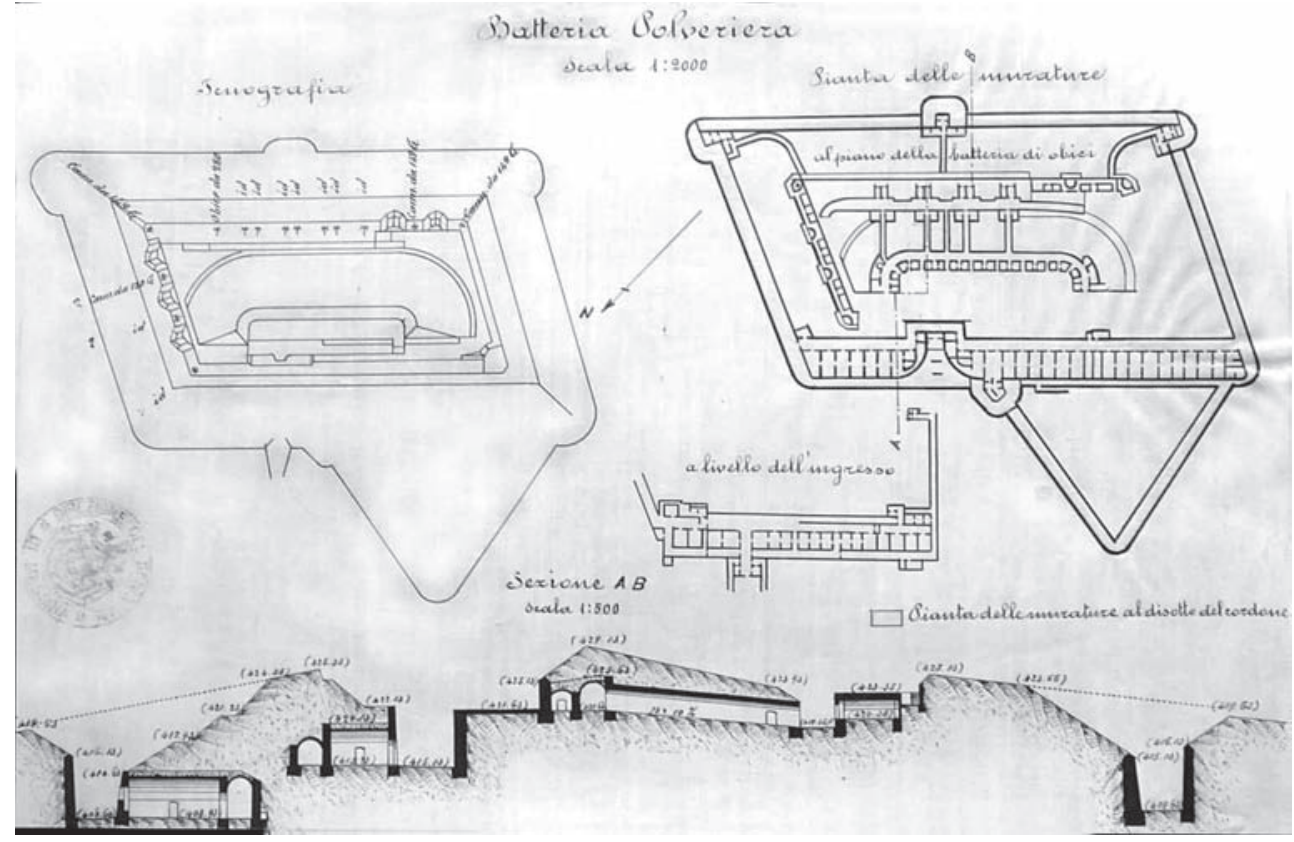

Fig. 5. Coast Battery Polveriera or Masotto, 1S Sicilian coast, plans and cross section. 


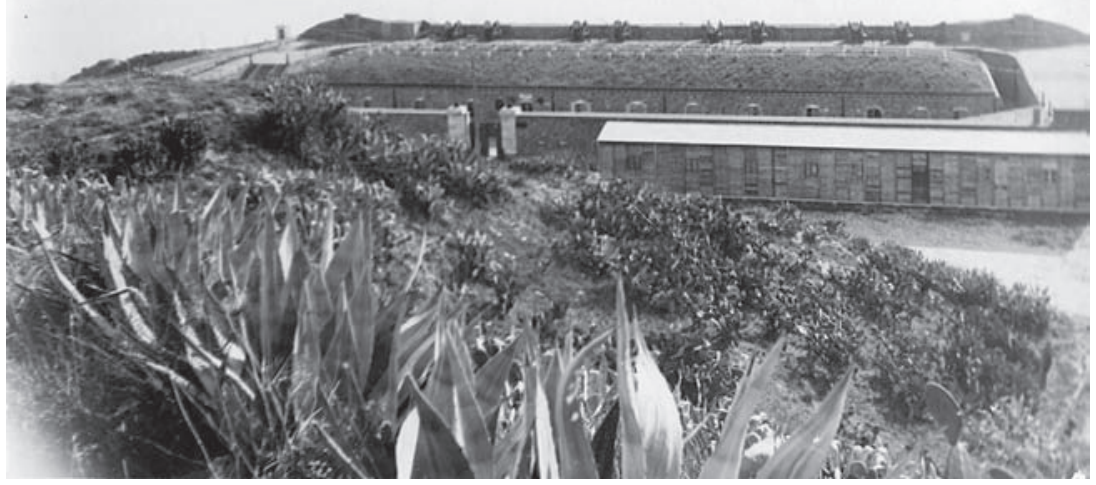

Fig. 6. Coast Battery Crispi or Menaja 2S, historic photo of the early twentieth century with howitzers ready to fire.

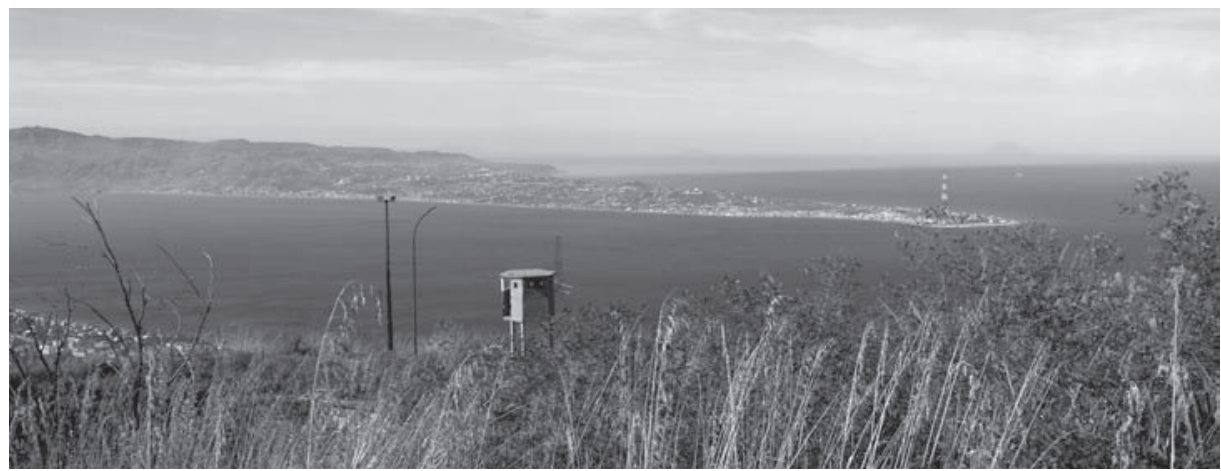

Fig. 7. The view of the Strait from the Coast Battery Poggio Pignatelli 3C.

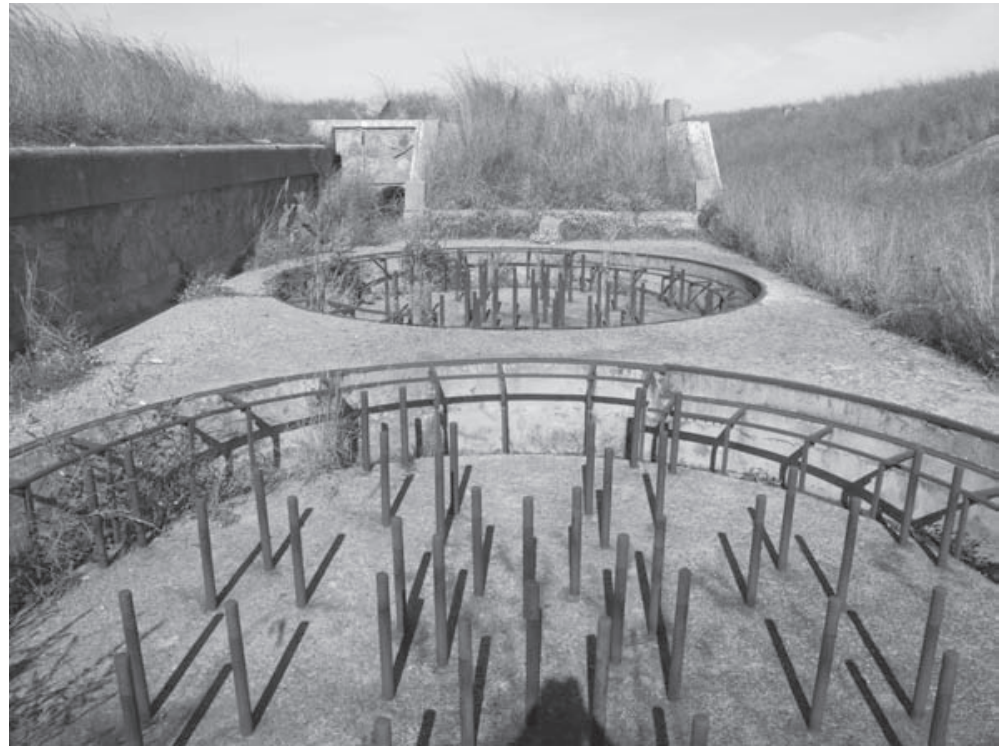

Fig. 8. Coast Battery Cimitero di Catona 5C, hooks of turntables Platforms for howitzers. 


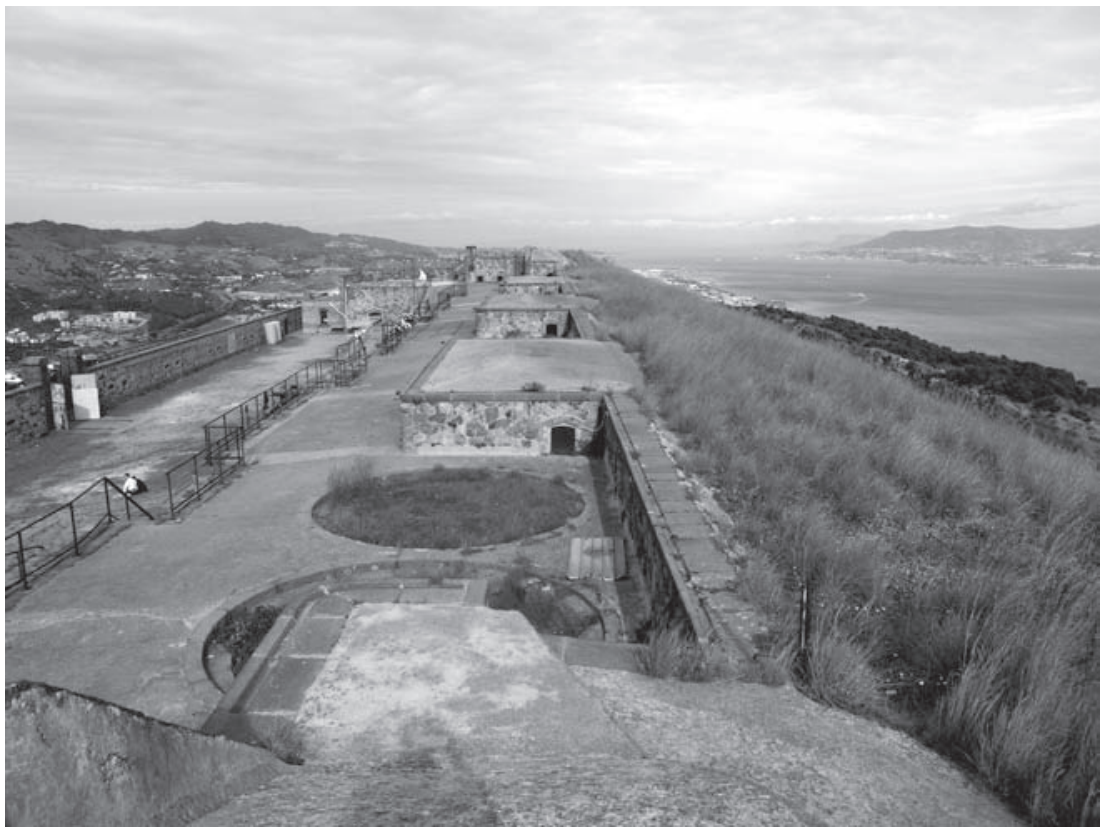

Fig. 9. Coast Battery Monte Gallo or Cavalli 7S shooting places and the Strait.

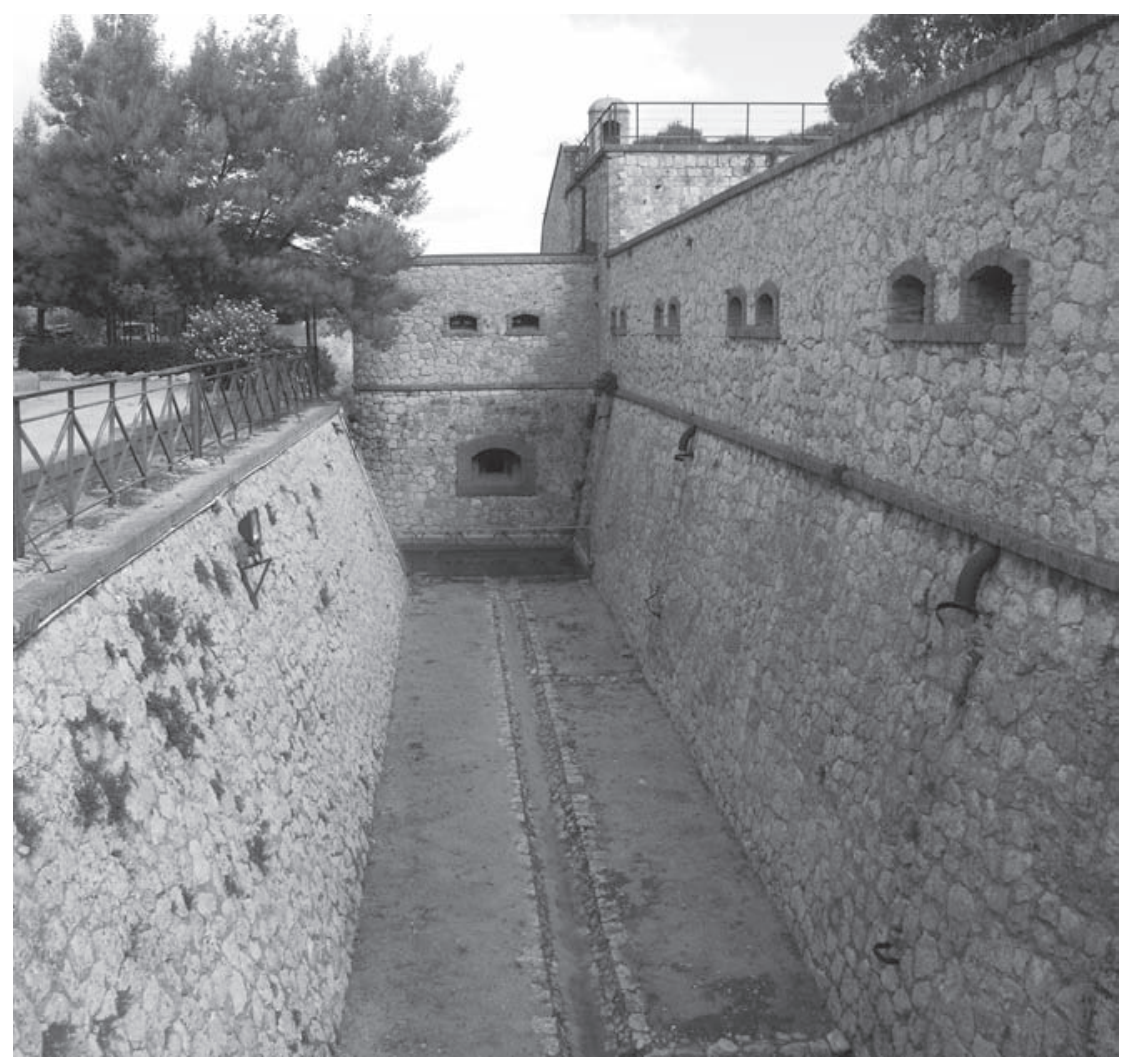

Fig. 10. Coast Battery San Jachiddu 8S, particularly of the ditch. 


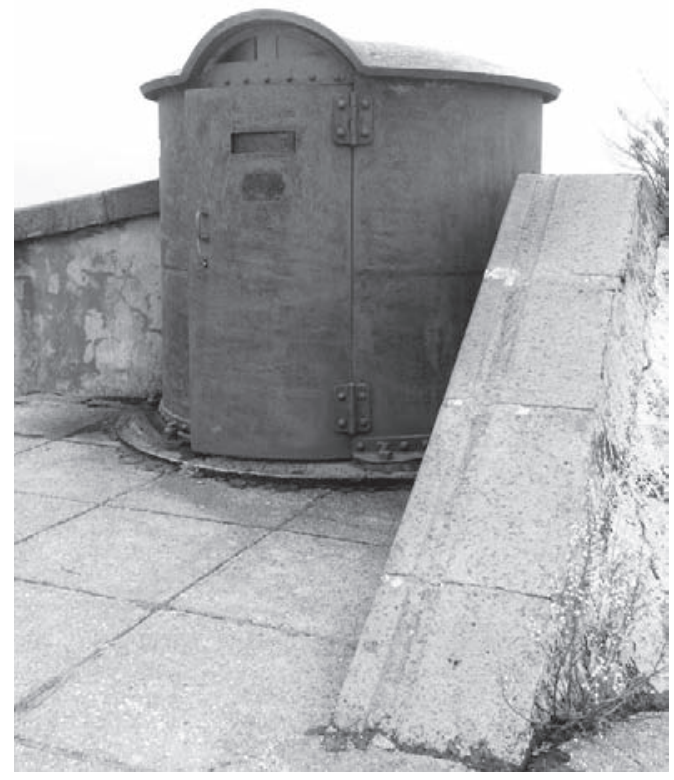

Fig. 11. Coast Battery Serra la Croce 9S, detail of the station telemetry.

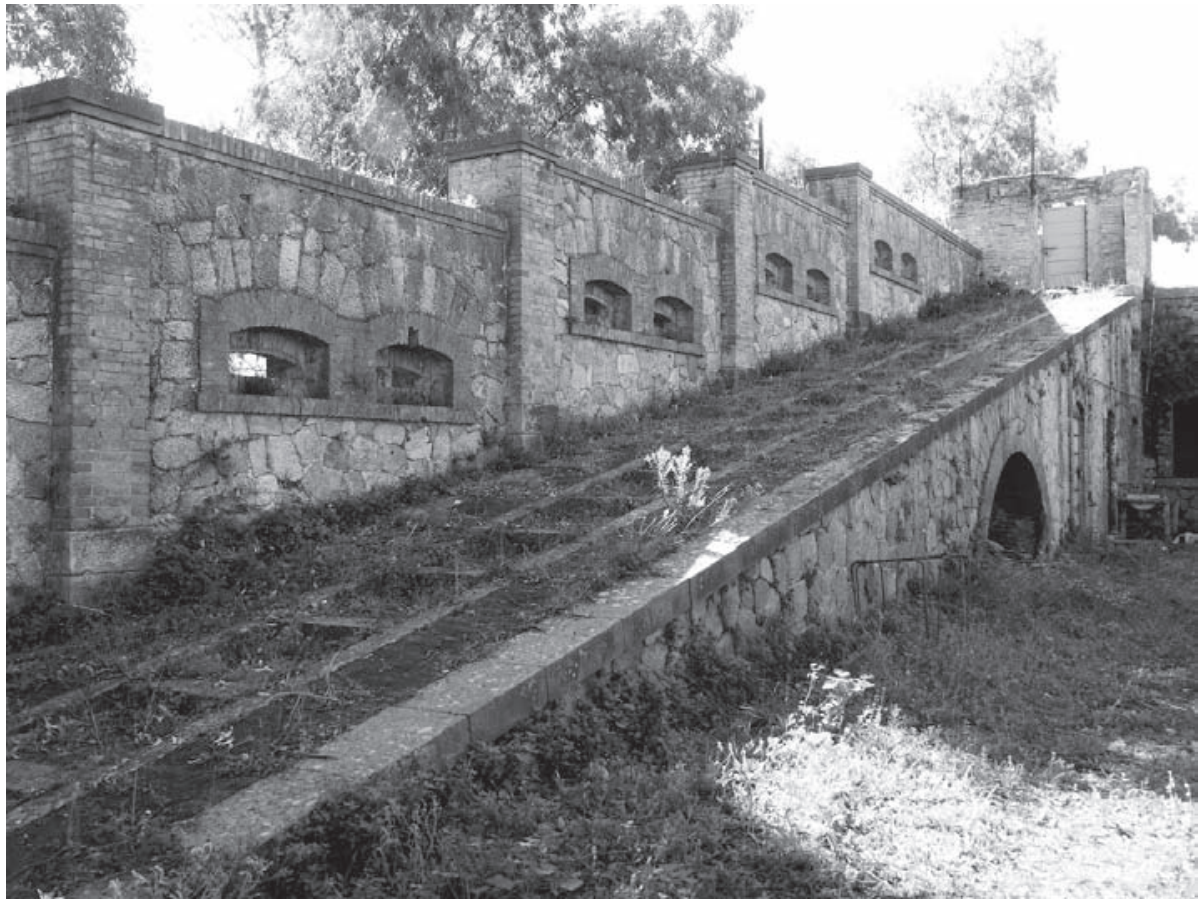

Fig. 12. Coast Battery Monte dei Centri 12S, detail of the ramp to the howitzers. 


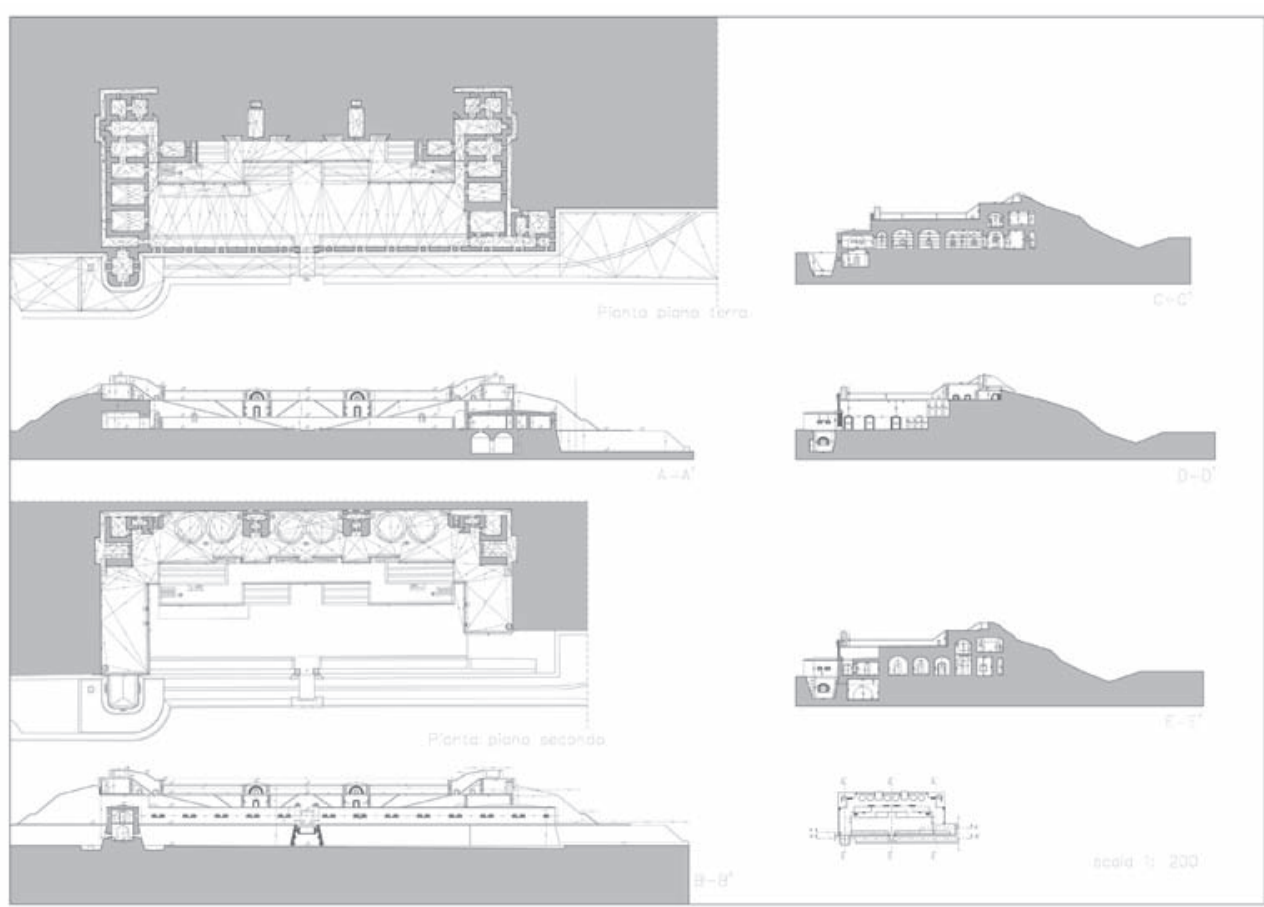

Fig. 13. Drawings of Coast Battery San Jachiddu 8S, architects Oteri, Donato, Biancuzzo. 
Table 1. Construction work on permanent fortifications of the Strait of Messina. Start of work November 1, 1884 to December 31, 1889.

\begin{tabular}{|c|c|c|c|c|}
\hline N. & SIC & CAL. & Permanent fortifications & $\begin{array}{l}\text { Date of start of } \\
\text { works }\end{array}$ \\
\hline 1. & & 1.C & Coast Battery Matiniti Superiore - SiaCCI & November 1,1884 \\
\hline 2. & $1 . S$ & & Coast Battery Polveriera- Masotto & November 1884 \\
\hline 3. & 2.5 & & Coast Battery MENAJA - CRISPI & August 20, 1887 \\
\hline 4. & 3.5 & & Coast Battery Pietrazza & January 1,1888 \\
\hline 5. & & 2.C & Coast Battery MATINITI INFERIORE & January 25, 1888 \\
\hline 6. & & 3.C & Coast Battery Poggio Pignatelli & January 25,1888 \\
\hline 7. & $4 . S$ & & Coast Battery Ogliastri & August 16, 1888 \\
\hline 8. & & 4.C & Coast Battery Telegrafo & September 1,1888 \\
\hline 9. & & 5.C & Coast Battery Cimitero di Catona & April 19, 1889 \\
\hline 10. & $5 . S$ & & Coast Battery MANGIALuPI & April 30, 1889 \\
\hline 11. & 6.5 & & Coast Battery Monte Giulitta - Schiaffino & June 17,1889 \\
\hline 12. & & 6.C & Coast Battery Pentimele Nord & July 11, 1889 \\
\hline 13. & 7.5 & & Coast Battery Monte Gallo - CaValli & July 1889 \\
\hline 14. & & 7.C & Coast Battery Pentimele Sud & July 11,1889 \\
\hline 15. & 8.5 & & Coast Battery S. JACHIDDU & July 19, 1889 \\
\hline 16. & & 8.C & Coast Battery PiAno di ARghilla' - Gullì & July 11, 1889 \\
\hline 17. & 9.5 & & Coast Battery Serra della Croce & August 17, 1889 \\
\hline 18. & $10 . S$ & & Battery Puntal Ferraro & September 19, 1889 \\
\hline 19. & $11 . S$ & & Blockhouse ANTENNAMARE & September 1889 \\
\hline 20. & $12 . S$ & & Battery Monte dei Centri & October 1889 \\
\hline 21 & 13.5 & & Battery Monte Campone & December 31, 1889 \\
\hline
\end{tabular}

$\mathrm{N} .=$ Progressive Numeration for date of start of works;

SIC = Batteries or blockhouse on the Sicilian coast;

CAL.$=$ Batteries or blockhouse on the Calabrian coast. 